\title{
PERBEDAAN PENGARUH MULTIPLE MICRO NUTRIENT (MMN) DAN MORINGA OLEIFERA TERHADAP KADAR HEMOGLOBIN TIKUS BUNTING
}

\author{
Dwi Retna Prihati, RD Rahayu \\ Kementerian Kesehatan Politeknik Kesehatan Surakarta Jurusan Kebidanan
}

\begin{abstract}
Multiple Micro Nutrient (MMN), Moringa Oleifera, Hemoglobin. Pregnant women are one of the vulnerable groups that may have anemia because hemodelusi events that occur during pregnancy. Multiple Micro Nutrient (MMN) is a supplement that contains multivitamins, iron and folate were given to pregnant women as one of the programs of the Ministry of Health of Indonesia in its efforts to prevent anemia during pregnancy. A survey found that $70 \%$ of pregnant women do not like the taste of Multiple Micro Nutrient (MMN) and in addition also the mother complain nausea, dizziness, palpitations, shortness of breath so hot and these supplements are not consumed and not consumed until exhausted if 120 tablet, See the above phenomenon it is necessary to alternative solutions, such as by utilizing vegetables such as Moringa oleifera. Iron content in $100 \mathrm{gr}$ dry leave Moringa oleifera is 28,2 $\mathrm{mg}$. The purpose of this study was to prove that no difference between the influence of Multiple Micro Nutrient (MMN) and Moringa oleifera against hemoglobin levels of pregnant rats. Ekperiment laboratory study design was randomized design with pre-post test with control group. Population is the first day of the pregnant rats, large samples of 24 rats. Twenty-four pregnant rats were randomly divided into 3 groups. Statistical analysis using Independent T-test. Significant value in this study was $p<0.05$. The results Independent T-test showed that Moringa oleifera has the same effect with Multiple Micro Nutrient in preventing a decline in hemoglobin levels in pregnant rats $(P=0,537)$.
\end{abstract}

Keywords: Multiple Micro Nutrient (MMN), Moringa Oleifera, Hemoglobin

Abstrak: Multiple Micro Nutrient (MMN), Moringa Oleifera, Kadar Hemoglobin. Ibu hamil merupakan salah satu kelompok yang rawan dapat mengalami anemia karena peristiwa hemodelusi yang terjadi saat kehamilan. Multiple Micro Nutrient (MMN) adalah suplemen yang berisi Multivitamin, zat besi dan folat yang diberikan pada ibu hamil sebagai salah satu program Kementerian Kesehatan Indonesia dalam upayanya mencegah anemia pada masa kehamilan. Hasil survei di lapangan menemukan bahwa $70 \%$ ibu hamil tidak menyukai rasa dari Multiple Micro Nutrient (MMN) dan selain itu juga ibu mengeluhkankan mual, pusing, jantung berdebar, panas dan sesak napas sehingga suplemen ini tidak dikonsumsi dan kalaupun dikonsumsi tidak sampai habis 120 tablet. Melihat fenomena diatas maka perlu solusi alternatif, diantaranya dengan memanfaatkan sayuran seperti Moringa Oleifera. Kandungan zat besi dalam Moringa Oleifera dalam $100 \mathrm{gr}$ serbuk daun sebesar 28,2 mg. Tujuan dari penelitian ini adalah membuktikan tidak adanya beda pengaruh antara Multiple Micro Nutrient (MMN) dan Moringa Oleifera terhadap kadar hemoglobin tikus bunting.Desain penelitian adalah ekperiment laboratory dengan rancangan randomized pre-post test group with control. 
Populasi adalah tikus bunting hari pertama, besar sampel 24 ekor. Dua puluh empat ekor tikus bunting dibagi secara random menjadi 3 kelompok. Analisis statistik menggunakan Independent T-test untuk. Nilai signifikan dalam penelitian ini adalah $\mathrm{p}<0,05$. Hasil penelitian Uji Independent T-test memperlihatkan bahwa Moringa Oleifera mempunyai pengaruh yang sama dengan Multiple Micro Nutrient dalam mencegah penurunan kadar hemoglobin pada tikus bunting $(\mathrm{P}=0,537)$.

Kata Kunci : Multiple Micro Nutrient (MMN), Moringa Oleifera, Kadar Hemoglobin

\section{PENDAHULUAN}

Ibu hamil merupakan salah satu kelompok yang rawan dapat mengalami anemia karena peristiwa hemodelusi yang terjadi saat kehamilan. Anemia ini akan semakin parah jika asupan gizi ibu tidak seimbang. Asupan gizi yang kurang tidak hanya berdampak anemia pada ibu tetapi juga gangguan pertumbuhan pada janin. Anemia pada kehamilan disebut dengan "Potencial danger of mother and child" yang berarti potensial membahayakan ibu dan anak. WHO melaporkan bahwa prevalensi anemia pada kehamilan di dunia adalah sebesar 55\% dan cenderung meningkat sesuai dengan bertambahnya usia kehamilan. Berdasarkan survei kejadian di Indonesia, prevalensi anemia ibu hamil mencapai 70 \%.( Cunningham, 2005; Manuaba, 1998).

Multiple Micronutrient (MMN) adalah suplemen yang berisi Multivitamin, zat besi dan folat yang diberikan pada ibu hamil sebagai salah satu program Kementerian Kesehatan Indonesia dalam upayanya mencegah anemia pada masa kehamilan. Multiple Micro Nutrient $(M M N)$ diberikan sebanyak 120 tablet dan diminum setiap hari. Hasil survey di lapangan menemukan bahwa $70 \%$ ibu hamil tidak menyukai rasa dari Multiple Micronutrient $(M M N)$ dan selain itu juga ibu mengeluhkankan mual, pusing, jantung berdebar, panas, sesak napas sehingga suplemen ini tidak dikonsumsi dan kalaupun dikonsumsi tidak sampai habis 120 tablet. Melihat fenomena diatas maka perlu solusi alternatif, diantaranya dengan memanfaatkan sayuran seperti Moringa Oleifera sebagai asupan nutrisi yang kaya akan zat besi untuk menurunkan angka kejadian anemia pada ibu hamil.

Moringa Oleifera atau yang lebih dikenal kelor kaya akan nutrisi, salah satunya adalah zat besi. Kandungan zat besi dalam Moringa Oleifera 25 kali lebih banyak dibandingkan bayam. Dalam 100 gram serbuk daun Moringa Oleifera terdapat $28,2 \mathrm{mg}$ zat besi dan $17,3 \mathrm{mg}$ vitamin C. Zat besi (Fe) adalah salah satu faktor pembentuk hemoglobin yang berfungsi mengangkut $\mathrm{O} 2$ keseluruh sel. Ketersediaan hemoglobin yang cukup membuat sistem metabolisme dapat berjalan dengan baik.

\section{METODE PENELITIAN}

Jenis penelitian ini adalah eksperimental laboratorium. Objek penelitian adalah tikus bunting hari pertama galur Wistar yang diberi Multiple Mikro Nutrient (MMN) dan Moringa Oleifera selama 20 hari dengan cara sonde. Rancangan penelitian yang digunakan adalah Randomized pre-post test group with control. Tempat pelaksanaan penelitian di laboratorium LPPT IV UGM Jogyakarta. Waktu 
penelitian dari bulan Januari 2015 sampai dengan Juni 2015. Penelitian ini menggunakan populasi tikus bunting hari pertama galur Wistar. Besar sampel yaitu sebanyak 24 ekor dan masing- masing kelompok yaitu, kelompok control sebanyak 8 ekor, kelompok P1 (diberi Multiple Mikro Nutrient (MMN) 2,7 mg/ hari) sebanyak 8 ekor dan kelompok P2 (diberi Moringa Oleifera 0,45 gr/hari) sebanyak 8 ekor. Teknik random yang dipakai adalah simple random sampling. Hasil uji Normalitas data dengan Saphiro Wilks menunjukkan bahwa semua data terdistribusi normal. Data kemudian dianalisis menggunakan Independent $T$ test. Nilai signifikan dalam penelitian ini adalah $\mathrm{p}<0,05$.

\section{HASIL PENELITIAN}

Rata-rata (mean) penurunan kadar hemoglobin dari pre dan post tikus bunting kelompok kontrol adalah 2,3 gr/dl , kemudian tikus bunting dengan perlakuan Multiple Micro Nutrient adalah 1,7 gr/dl dan tikus bunting dengan perlakuan Moringa Oleifera adalah 1,8 gr/dl. Hal ini menunjukkan bahwa penurunan kadar hemoglobin tertinggi terdapat pada tikus bunting kontrol. Berdasarkan uji independent T-test antara kelompok kontrol dan kelompok P1 menunjukkan angka $\mathrm{p}=0,24$ sedangkan antara kelompok kontrol dan kelompok P2 menunjukkan angka $p=1,00$. Hasil analisis statistik perbandingan penurunan Kadar hemoglobin induk bunting yang diberi perlakuan Multiple Micro Nutrient dan Moringa Oleifera ditampilkan pada tabel dibawah ini.

Dari angka Independent T-test didapatkan nilai $\mathrm{p}=0,537$ yang berarti, tidak terdapat perbedaan penurunan kadar hemoglobin yang bermakna antara kelompok yang diberi perlakuan Multiple Micro Nutrient dan Moringa Oleifera.

\section{PEMBAHASAN}

Rerata penurunan kadar hemoglobin pada kelompok kontrol lebih besar dari pada kelompok perlakuan. Rerata penurunan kadar hemoglobin kelompok P1 lebih rendah dibandingkan kelompok P2. Kecenderungan penurunan kadar hemoglobin pada tikus bunting sejalan dengan peningkatan usia kebuntingan. Hal ini sesuai dengan Abdulmuthalib (2008) bahwa selama kehamilan akan mengalami peristiwa hemodelusi sehingga kadar hemoglobin menurun. Varney (2007) menyebutkan bahwa peningkatan volume darah total dimulai pada awal trimester pertama yang kemudian meningkat pesat hingga pertengahan kehamilan kemudian melambat hingga menjelang minggu ke32. Setelah itu eritrosit tetap. Sejalan dengan Abdulmutholib dan Varney, Cuningham (2006) menyebutkan bahwa selama kehamilan terjadi peningkatan plasma dalam darah. Peristiwa ini mengakibatkan kadar hemoglobin menjadi turun hingga akhir kebuntingan. Pada saat hamil, oksigen dibutuhkan lebih tinggi sehingga memicu peningkatan produksi eritropoetin, Akibatnya volume plasma dan sel darah merah (eritrosit) bertambah. Namun, peningkatan volume plasma terjadi dalam proporsi yang lebih besar jika dibandingkan dengan peningkatan eritrosit sehingga terjadi penurunan konsentrasi hemoglobin (hemodelusi). Hemodelusi berfungsi untuk menurunkan kekentalan darah maternal sehingga meningkatkan perfusi plasental dan membantu penghantaran oksigen dan nutrisi ke janin. 
Dari uji independent T-test baik Multiple Micro Nutrient ataupun Moringa Oleifera dibandingkan dengan kelompok kontrol menunjukkan angka masingmasing $\mathrm{p}=0,24$ dan $\mathrm{p}=1,00$. Ini berarti keduanya tidak signifikan dalam mencegah penurunan kadar hemoglobin saat terjadi hemodelusi dalam kebuntingan tikus. Meskipun demikian, dari nilai rata-rata (Mean) dibandingkan kelompok kontrol, keduanya berhasil mencegah penurunan kadar hemoglobin sebanyak 0,6 gr/dl untuk Multiple Micro Nutrient dan 0,5 gr/dl untuk Moringa Oleifera.

Berdasarkan rata-rata (Mean) penurunan hemoglobin dapat dilihat bahwa Multiple Micro Nutrient dapat mencegah lebih banyak penurunan kadar hemoglobin dalam peristiwa hemodelusi daripada Moringa Oleifera. Hal ini dikarenakan dalam Moringa Oleifera tidak terkandung asam folat dan vitamin B12 sebagai bahan pembentuk hemoglobin selain $\mathrm{Fe}$ seperti pada Multiple Micro Nutrient. Hasil uji Independent T-test menunjukkan angka $\mathrm{p}=0,537$, hal ini menunjukkan bahwa tidak ada beda yang significant antara penurunan kadar hemoglobin pada kelompok tikus bunting yang diberi perlakuan Multiple Micro Nutrient dan Moringa Oleifera, dengan kata lain Moringa Oleifera dapat menggantikan tablet Multiple Micro Nutrient dalam usaha mencegah penurunan kadar hemoglobin dalam peristiwa hemodelusi dalam kehamilan. Hal ini sesuai dengan penelitan While Gopalan (2010) bahwa dalam 100 gr serbuk daun kelor terdapat 28,2 zat besi dan 17,3 vitamin C. Zat besi diperlukan untuk bahan pembentukan hemoglobin, sedangkan vitamin $\mathrm{C}$ dapat membuat zat besi dalam daun kelor terserap tubuh dengan maksimal saat dikonsumsi.

Secara teori Proses absorbsi besi dalam usus terdiri dari 3 fase yaitu fase luminal, fase mucosal, dan fase sistemik atau korporeal (Bakta, 2000). Pada fase luminal ikatan besi dari bahan makanan (kelor) dilepaskan atau dirubah menjadi bentuk terlarut dan terionisasi. Kemudian besi dalam bentuk feri $\left(\mathrm{Fe}^{3+}\right)$ direduksi menjadi bentuk fero $\left(\mathrm{Fe}^{2+}\right)$ sehingga siap diserap usus. Dalam proses ini getah lambung memegang peranan penting. Absorbsi paling baik terjadi pada duodenum dan jejenum proksimal. Hal ini dihubungkan dengan jumlah reseptor pada permukaan usus dan $\mathrm{pH}$ usus. Dalam 100 gram serbuk kelor mengandung banyak asam amino yang disini dapat membantu mencegah terjadinya proses polimerisasi dan presipitasi besi. Selain itu, pada kelor terdapat vitamin c (asam askorbat) yang merupakan bahan pemacu absorbsi besi yang sangat kuat yang berfungsi sebagai reduktor yang dapat mengubah feri menjadi fero, mempertahankan $\mathrm{pH}$ usus tetap rendah sehingga mencegah presipitasi besi dan bersifat sebagai monomeric chelator yang membentuk iron-ascorbate chelate yang lebih mudah diserap oleh tubuh. Setelah itu, besi diserap secara aktif melalui reseptor. Jika dosis terlalu besar besi akan masuk secara difusi pasif. Dalam sel enterosit besi akan diikat oleh suatu karier protein spesifik dan ditransfer melalui sel ke kapiler atau disimpan dalam bentuk ferritin dalam enterosit kemudian dibuang bersamaan dengan deskuamasi epitel usus. Pada fase sistemik, besi yang masuk ke plasma akan diikat oleh apotransferin menjadi transferrin dan diedarkan ke seluruh tubuh, terutama ke sel eritroblast dalam sumsum tulang. Semua sel mempunyai 
reseptor transferrin pada permukaannya. Transferrin ditangkap oleh reseptor ini dan kemudian melalui proses pinositosis (endositosis) masuk dalam vesikel (endosome) dalam sel. Akibat penurunan $\mathrm{pH}$, besi, transferrin, dan reseptor akan terlepas dari ikatan. Besi akan dipakai oleh sel sedangkan reseptor dan transferrin dikeluarkan untuk dipakai ulang. Selanjutnya zat besi $(\mathrm{Fe})$ bersamasama dengan asam folat dan vitamin B12 akan berproses untuk menjadi hemoglobin. Hemoglobin yang berfungsi mengangkut $\mathrm{O} 2$ keseluruh sel. Ketersediaan hemoglobin yang cukup membuat sistem metabolisme dapat berjalan dengan baik.

\section{KESIMPULAN DAN SARAN}

Berdasarkan penyajian data dan pembahasan pada bab sebelumnya, maka dari penelitian ini dapat diambil simpulan sebagai berikut:

1. Berdasarkan nilai rata-rata (mean), Multiple Micro Nutrient dan Moringa Oleifera dapat mencegah penurunan kadar hemoglobin pada tikus bunting masing-masing sebanyak $0,6 \mathrm{gr} / \mathrm{dl}$ dan $0,5 \mathrm{gr} / \mathrm{dl}$ dibandingkan dengan kelompok kontrol

2. Tidak ada perbedaan penurunan kadar hemoglobin yang signifikan antara kelompok Kontrol dengan kelompok Multiple Micro Nutrient $(\mathrm{p}=0,24)$ ataupun antara kelompok kontrol dengan kelompok Moringa Oleifera $(\mathrm{p}=1,00)$

3. Moringa Oleifera mempunyai pengaruh yang sama dengan Multiple Micro Nutrient dalam mencegah penurunan kadar hemoglobin pada tikus bunting $(\mathrm{P}=0,537)$.

4. Masyarakat terutama ibu hamil dapat mengkonsumsi Moringa Oleifera sebagai solusi alternatif untuk mencegah penurunan kadar hemoglobin saat hamil selain tablet Multiple Micro Nutrient .

5. Melihat dari hasil penelitian ini maka perlu penelitian lebih lanjut sekaitan keefektifan konsumsi dan efektivitas tablet Multiple Micro Nutrient untuk ibu hamil .

\section{DAFTAR RUJUKAN}

Abdulmuthalib (2008) Kelainan Hematologi Dalam Buku Ilmu Kebidanan. Jakarta: Bina Pustaka;. hal 774-780

Cunningham G.F., Gant N.F., Leveno K.J., et all. 2006. Obstetri Williams vol 1 edisi 21 . Jakarta: EGC:

Guyton (1997) Fisiologi Kedokteran, Jakarta, EGC

Nita Dalmiya, Ian Darnton-Hill, Werner Schultink, and Roger Shrimpton (2009). Multiple micronutrient upplementation during pregnancy, Food and Nutrition Bulletin, vol. 30, no. 4 (supplement) United Nations University Press

Dinas Kesehatan Klaten. 2012. Petunjuk Tehnis MMN

Robert K. Murray (2006). Sel Darah Merah Dan Putih Dalam Buku Biokimia Harper edisi 27 . Jakarta: EGC; , hal 636-652

Sugiyono (2007). Statistika Untuk Penelitian. Bandung: CV Alfabeta

Varney, Helen. (2007). Buku Ajar Asuhan Kebidanan Edisi 4 Volume 1. Jakarta:EGC 